\title{
МІСЦЕ УКРАЇНСЬКОГО БІЗНЕСУ В ЄВРОПЕЙСЬКОМУ ЕНЕРГЕТИЧНОМУ ПРОСТОРІ
}

\author{
Калініченко Л.Л., д-р екон. наук, професор \\ Багмут Л.С., канд. екон. наук, доцент \\ Харківський національний університет будівництва та архітектури
}

Постановка проблеми У розв'язанні нагальних проблем Європи особливе місце належить енергетиці, від розвитку якої залежить занепад або процвітання суспільства, а також стан навколишнього середовища. Будь-які види діяльності людини, усі здобутки сучасної цивілізації - все це стало можливим завдяки використанню різних джерел енергії. Саме тому створення i розробка енергетичних ресурсів, вироблення, перетворення, передача та використання різноманітних видів енергії - найважливіша галузь і основа економіки будь-якої країни і підвищення якості життя людей. Сучасний стан енергетики i рівень організації міжнародного співробітництва недостатньо відповідають сучасним викликам безпеки та екологічним стандартам.

Аналіз останніх досліджень і публікацій. Споживання енергії різник типів, їх постачання та бізнес-середовище енергоринку Європи вивчаються досить давно та щільно. Формування європейського енергетичного простору у всьому його різноманітті вивчали такі вітчизняні науковці, як: Бараннік В, Бурлака Г., Волович О., Земляний М., Саприкін В., Шевцов А. Проблеми функціонування енергетичних ринків на теренах Європи досліджувалися значною кількістю російських авторів, серед яких Баграмян I.С, Зонова Л., Лось С., Мінаєва С., Мітрова Т. та багато інших.

Всі автори розглядають безпеку енергопостачання та створення конкурентного бізнес-середовища в сфері імпорту та розподілу енергоносіїв як пріоритетне завдання державних установ.

Невирішені складові загальної проблеми. В сучасних умовах економічного життя Європейських країн головною проблемою сталого розвитку була та залишається надійність поставок різноманітних енергоресурсів. Відносно новою проблемою постає зміна структури енергобалансу на екологічні складові.

Формулювання цілей статі. Метою статті $є$ всебічний аналіз складових сучасного енергетичного балансу Європи та виявлення суттєвих зрушень у його структурі.

Виклад основного матеріалу дослідження. Вуглеводневі джерела та вугілля в даний час продовжують відігравати провідну роль у світовому енергетичному балансі. У тому числі вугілля, що забезпечує до третини глобального попиту на енергію та близько $40 \%$ викидів вуглекислого газу [1]. 
У 2019 році частка поновлюваних джерел енергії (ПДЕ) в сукупних встановлених потужностях перевершила світову частку вугілля. Варто відзначити, що вироблення електроенергії на одиницю потужності відрізняється в кілька разів по різних типах генеруючих потужностей. Якщо станції, що працюють на вугіллі, можуть працювати безперервно, то вітряні або сонячні установки цього робити не можуть. Тому потенційно вони виробляють менше електроенергії, навіть якщо їх потужність перевищує вугільні. На вугільні електростанції в 2019 році припадало майже 40\% усієї вироблюваної в світі електроенергії, а на поновлювані джерела (включаючи ГЕС) - менше четвертої частини.

3 початку 21 століття головною ознакою світової та європейської енергетики $є$ інтенсивне розгортання трьох революцій: «сланцевої революції», сонячної революції та повітряної революції. У США продовжується бум видобутку сланцевого газу - нові технології значно знижують собівартість. За останні 15 років собівартість видобутку сланцевого газу в США знизилася на $70-80 \%$, частка в загальному видобутку наближається до $60 \%$. Знижується вартість буріння свердловин, росте кількість гідророзривів на одному коліні. Очевидне здешевлення сонячних модулів (щорічно на 10\%) за рахунок технологічних i наукових розробок [2]. На початку 2016p. аналітики повідомили, що електрика з відновлюваних джерел енергії, що не субсидуються місцевим урядом, нині обходиться дешевше, ніж з нещодавно побудованих газових або вугільних електростанцій. Станом на першу половину 2020 року повітряна електроенергія втратила свою конкурентоспроможність через розгортання світової економічної кризи. Немає сумнівів у екологічності природного газу, ціни на нього на початку 3-го кварталу 2020 року на європейських хабах знизилися до 50-70 дол. за 1000 куб. м.

Світові та європейські ринки природного газу стають все більш синхронізованими на тлі створення нових потужностей зі зрідження газу, що полегшують завдання по доставці палива в будь-яку точку світу. Зближенню цін на різних ринках сприяе активне будівництво СПГ- терміналів. На думку експертів, до кінця 2020 року сукупна потужність усіх терміналів в світі складе до 350-400 млн. тонн. Очікується, що в першій половині 20-х років в експлуатацію будуть введені більше 100 млн тон потужностей [3].

Продовжується енергетична політика Євросоюзу щодо зміцнення незалежності від ненадійних постачальників. Бажаючи позбутися диктату Газпрому, європейці почали шукати можливість звести споживання російських енергоносіїв до мінімуму. Для цього вони звернули свій погляд у бік США, які в останні роки стрімко перетворюються зі споживача нафти і газу на їхнього експортера.

Ресурси сланцевого газу в США величезні, а інфраструктура добре розвинена. Собівартість видобутку знижується щорічно і на початку 2020 року складає від 30 до 70 доларів за тисячу куб. м. Для покращення енергобалансу Європи США згодилися експортувати значні кількості газу починаючі з 2018 
року. Але слід відзначити, що масштабні поставки газовозів та будівництво терміналів припадають на 2019-2022 рр. Тому країни Свропи в цей же час роблять все можливе, щоб побудувати газопроводи з Близького Сходу. Вступ до ЄС таких країн, як Болгарія та Румунія відкриває можливості транзиту нафти та газу з Каспійського басейну, тобто диверсифікації їх постачань.

Позбавлення Європи та України енергетичної залежності від Росії - $€$ справою середньострокової перспективи. Ніхто 3 країн Євросоюзу не збирається відмовлятися від російських енергоносіїв - мова йде про скорочення iї частки в структурі імпорту до рядових значень[4].

При цьому величезна економіка Свропи - німецька - у своїй енергетичній політиці керується останніми роками концепцією «енергетичного повороту», який передбачає поступову відмову від вуглеводневої та атомної енергетики та перехід на ії відновлювані джерела, а також більш економне та дбайливе використання енергії.

Основними цілями реалізації «енергетичного повороту» $є$ боротьба зі зміною клімату; зниження залежності від імпорту енергоносіїв (Німеччина не має нафти і газу, але володіє великими запасами вугілля); стимулювання розвитку технологічних інновацій та «зеленої економіки»; зменшення ризиків використання атомної енергії; боротьба 3 монополіями в енергетичному секторі тощо. Згідно з новою політикою, до 2025 року потрібно збільшити частку електроенергії з альтернативних джерел до 40\%, до 2032 року Німеччина має намір повністю зупинити роботу всіх АЕС [3].

Друга за потужністю економіка Європи - французька, на відміну від небагатьох країн світу, не володіє достатніми для забезпечення власних енергетичних потреб природними ресурсами, тому ще 3 минулого століття активно розвиває атомну енергетику. Атомна енергетика виробляє 76,9\% електроенергії у Франції. Станом на кінець 2019 року Франція має 19 діючих $\mathrm{AEC}$, на яких працює 58 промислових ядерних реакторів сумарною потужністю 63,2 ГВт. За обсягами енергії, що виробляють атомні станції, країна посідає друге місце в світі, а за часткою атомної енергетики - перше місце в світі. Франція - найбільший експортер електроенергії в світі, веде активні дослідження в галузі атомної енергетики, володіє технологіями з виробництва реакторів, виробництва та утилізації палива.

Уряд Франції прийняв енергетичну програму, яка передбачає детальний розвиток галузі 3 виробництва електроенергії за видами (атомна, газова, відновлювальні джерела енергії тощо). За даними нацкомісії 3 охорони довкілля, рівень інвестицій у французьку енергетику упродовж до 2035 року становитиме 400 млрд євро. За оцінками експертів, вартість електроенергії, що виробляється на АЕС країни, до 2030 року залишиться найнижчою. Але технічний прогрес згодом дозволить газовій та повітряній електриці конкурувати з нею [7].

Ситуація в українській енергетиці $є$ занадто особливою: потужна i сучасна енергосистема ще зберігається на тлі деградації промислового 
потенціалу. Основою електроенергетики України були і залишаються на середньостроковий період атомні електростанції (АЕC). Гігантські капіталовкладення, стала робота, дешевина продукції обумовлюють їх абсолютний пріоритет над усіма іншими джерелами енергії.

На сьогодні Україна входить до десятки країн світу, які найбільше використовують ядерну енергію для виробництва електричної енергії. За кількістю енергетичних реакторів Україна посідає десяте місце у світі та п'яте в Європі, усі реактори типу ВВЕР російського виробництва. В Україні діють чотири AEC 315 енергоблоками (загальна встановлена потужність 13,835 ГВт), одна 3 яких - Запорізька AEC з 6 енергоблоками загальною встановленою потужністю $6000 \mathrm{MBт}-\epsilon$ найбільшою в Європі [5].

Збереження потенціалу в атомній енергетиці, яку відносять до передових, високих технологій і дозволяє розвиватися економіці в умовах виснажених інших джерел. Чотири діючих AEC і найбільші в Європі родовища урану - це анклав постіндустріального суспільства в Україні. До того ж це найдешевша (після ГЕС) енергія, яка сьогодні доступна людству і яка дає Україні $50 \%$ електроенергії. Найважливішою подією в атомній енергетиці України є початок включення іï в ланцюжки глобальної економіки: в 2016 році є встановлення першої партії палива американського виробництва. До середини 2020 років Україна зможе позбутися залежності від Росії щодо ядерного палива [4].

Газова промисловість України - друга за потенціалом складова енергетики. Гібридна війна 3 Росією змусила керівництво країни повністю відмовитися від імпорту російського газу. Загалом, частка газового імпорту 3 Росії знизилась з 74\% у 2014 році до 37\% у 2015 і до 0\% у 2017 році. Це значне досягнення, оскільки нові маршрути постачання газу дозволяють Україні вибирати постачальника з найнижчою ціною.

Україна за роки своєї незалежності. скоротила споживання газу з 90 млрд кубометрів у 1992 році до 50 млрд кубометрів у 2013 році і до 31 млрд кубометрів у 2019 році. Зрозуміло, що така економія в значній мірі мала місце через суттєве падіння обсягів виробництва.

Україна була і залишається країною, залежною від зовнішніх поставок енергоресурсів. Імпортується все: природний газ, нафтопродукти, ядерне паливо і навіть вугілля. Обладнання для традиційної та альтернативної енергетики також купується за кордоном. Слід зазначити, що завдяки зусиллям європейської бюрократії з 2020 року Україна відновила імпорт природного газу iз Росії на виключно вигідних умовах. Важливою ознакою ситуації в енергетиці $\epsilon$ надзвичайна енерговитратність українській економіки. На виробництво одиниці продукції Україна витрачає у 4-8 разів більше енергії, ніж у країнах, які досягли значних результатів у галузі енергозбереження. Для того, щоб заробити 1000 дол. ВВП Україна витрачає енергоресурсів в 4 рази більше, ніж в Польщі, в 5 разів більше, ніж у Литві, і в 8 разів більше, ніж у Німеччині. Ситуація 3 використанням природного газу абсолютно незадовільна. На виробництво 1000 дол. ВВП Україна витрачає газу в 4 рази більше, ніж Румунія 
і Литва, у 9 разів більше Польщі, і в 13 разів більше Німеччини. Маючи розмір ВВП в 5 разів менший, ніж у Польщі, у цьому році Україна спожила природного газу в 2 рази більше [6].

Слід зазначити, що наша країна має великий потенціал для підвищення рівня енергозабезпечення за рахунок внутрішніх резервів. Запаси природного газу становлять близько 1 трильйона кубометрів (вистачить на 30 років), нафти і газового конденсату - 200 млн тонн (на 50 років). Запаси бурого вугілля становлять близько 8 млрд тонн, їх вистачить на 300 років. Запаси сланцевого газу - близько 5 трлн кубометрів [8]. Потужності нафтопереробних заводів дозволяють не тільки повністю забезпечити країну нафтопродуктами, але й активно їх експортувати. При цьому можливості альтернативної енергетики (вітряна, сонячна, на біомасі) використовуються не більше ніж на 5\%. Замість розвитку власної ресурсної бази, Україна всі роки йшла найпростішим і дуже неефективним шляхом - збільшуючи закупівлі по імпорту. Суттєве підвищення енергоефективності - у створенні ефективного і збалансованого енергоринку.

Висновки 3 проведеного дослідження. 3 техніко-економічної точки зору Україна має великі можливості щодо самозабезпечення себе енергією зі всіх джерел. Але на шляху практичної реалізації потужностей постають значні проблеми, які не вирішити протягом наступних років. Слід перелічити проблеми, що суттєво перешкоджають досягненню самозабезпечення нашою країною: проблеми інвестиційного клімату, проблеми неефективного енергоспоживання, значний негативний вплив на розвиток відновлюваної енергетики спричиняє також низький рівень екологічної свідомості населення. Проблему становить державна політика в галузі екології та енергетики. Щодо ситуації на енергопросторі Європейського Союзу можна зазначити, що: Європейський Союз продовжує проводити політику витіснення Газпрому 3 ринку; Країни СС продовжують будівництво терміналів для прийняття скрапленого газу, що підвищує їх незалежність; альтернативні види енергії в Європі продовжують підтримуватися із бюджету.

\section{Перелік посилань}

1. Кулагина В. Газовый рынок Европы. ИНЕИ РАН. М., 2016. 86 с.

2. Цилибина В. Прогноз развития мирового энергетического рынка. Наука та наукознавство. 2018. №1. С. 73-91.

3. Прогноз развития энергетики 2017 года на период по 2040 год включительно. Основные тезисы. URL: http://cdn.exxonmobil.com/ /media/russia/files/outlook-for-energy/outlook-forenergy_highlights_2017_rus.pdf. (дата звернення: 11.10.2020).

4. Гріненко А. Ю. Сучасні проблеми енергетичної безпеки України у трансформаційному світі. Наукові записки Національного університету «Острозька академія». 2018. №o 9. С. 4-10.

5. Матвійчук Н. М. Пріоритетні напрями забезпечення енергетичної безпеки України. Економічний форум. 2018. №o 2. С. 183-187. 
6. Лесюк В. С. Напрями забезпечення енергетичної безпеки України. Енергоефективність та енергозбереження: економічний, техніко-технологічний та екологічний аспекти: колективна монографія / за заг. ред. П. М. Макаренка, О. В. Калініченка, В. І. Аранчій. Полтава : ПП «Астрая», 2019. 603 с.

7. Суходоля О. М. Проблеми визначення сфери регулювання енергетичної безпеки. Стратегічні пріоритети. 2019. № 1. С. 5-17.

8. Скрипник А. В., Намясенко Ю. О. Оптимізація газопостачання як складова енергетичної стратегії України. Проблеми економіки. 2017. №3. С. $87-94$.

9. Державна служба статистики України. URL: http://www.ukrstat.gov.ua. (дата звернення: 11.10.2020).

\section{References}

1. Kulagina, V. (2016), European gas market [Gazovyj rynok Evropy], INEI RAS, M., 86 p.

2. Tsilibina, V. (2018), Forecast of the world energy market development [Prognoz razvitija mirovogo jenergeticheskogo rynka], Science and Science, No 1, P. $73-91$.

3. Forecast of energy development in 2017 for the period up to 2040 inclusive Maitheses [Prognoz razvitija jenergetiki 2017 goda na period po 2040 god vkljuchitel'no Osnovnye tezisy], available at http://cdn.exxonmobil.com/ /media/russia/files/outlook-for-energy/outlook-forenergy_highlights_2017_rus.pdf. (last accessed 11.10.2020).

4. Grinenko, A.Yu. (2018), Modern problems of energy security of Ukraine in the transformational world [Suchasni problemi energetichnoï bezpeki Ukraïni $u$ transformacijnomu sviti], Scientific notes of the National University «Ostroh Academy», No 9, P. 4-10.

5. Matviychuk, N. M. (2018), Priority areas for energy security of Ukraine [Prioritetni naprjami zabezpechennja energetichnoï bezpeki Ukraïni], Economic forum, No 2, P. 183-187.

6. Lesyuk, V. S. (2019), Directions for energy security of Ukraine. Energy efficiency and energy saving: economic, technical and technological and environmental aspects [Naprjami zabezpechennja energetichnoï bezpeki Ukrä̈ni. Energoefektivnist' ta energozberezhennja: ekonomichnij, tehniko-tehnologichnij ta ekologichnij aspekti], a collective monograph, Col. authors; for general ed. P. M. Makarenko, O. V. Kalinichenko, V. I. Aranchiy, Poltava: PP «Astraya», 603 p.

7. Suhodolja, O. M. (2019), Problems of determining the scope of energy security regulation [Problemi viznachennja sferi reguljuvannja energetichnoï bezpeki], Strategic priorities, No 1, P. $5-17$.

8. Skripnik, A. V., Namyasenko, Y. O. (2017), Optimization of gas supply as a component of Ukraine's energy strategy [Optimizacija gazopostachannja jak skladova energetichnoï strategiï Ukraïni], Problems of the economy, No 3, P. 87-94.

9. State Statistics Service of Ukraine [Derzhavna sluzhba statistiki Ukraïni], available at : http://www.ukrstat.gov.ua. (last accessed 11.10.2020). 


\section{РЕФЕРАТИ РЕФЕРАТЫ ABSTRACTS}

\section{УДК 656.01; JEL Classification: R40}

\section{Калініченко Л.Л., БаГмУТ Л.С. МІСЦЕ УКРАЇНСЬКОГО БІЗНЕСУ В ЄВРОПЕЙСЬКОМУ ЕНЕРГЕТИЧНОМУ ПРОСТОРІ}

Мета дослідження полягає у виявленні тенденцій та закономірностей функціонування структур паливно-енергетичного комплексу України та країн Європи. Методика дослідження. Для досягнення поставленої мети у науковій роботі були використані методи аналізу та синтезу, узагальнення та абстрагування - для систематизації тенденцій розвитку головних галузей паливно-енергетичного комплексу. Метод комплексного підходу до аналізу явищ допоміг здійснити структуризацію проблемних питань. Результати дослідження. У підготовки даної статті розглянуто значну кількість наукових праць та статей на тему енергетики та енергопостачання в рамках європейського регіону. Виявлено, що до головних питань енергетичної безпеки у авторів немає розходжень. Системний аналіз статистичного матеріалу дав змогу оформити найважливіші тенденції розвитку енергетики Євросоюзу та України. Для країн Свропи головним зрушенням в галузях ПЕК є зниження долі ненадійних постачальників енергоресурсів і надзвичайно капіталоємна політика заміщення вугільної генерації на повітряну. Виявлені проблеми, що суттєво перешкоджають досягненню самозабезпечення нашою країною: проблеми інвестиційного клімату, проблеми неефективного енергоспоживання, низький рівень екологічної свідомості населення. Проблему становить державна політика в галузі екології та енергетики. На енергопросторі Європейського Союзу можна зазначити, що країни $Є С$ продовжують будівництво терміналів для прийняття скрапленого газу, що підвищує їх незалежність; альтернативні види енергії в Європі продовжують підтримуватися із бюджету. Наукова новизна. Полягає у підкресленні надзвичайних заходів країн Європейського союзу щодо створення розгалуженої системи 3 багатьох постачальників енергоресурсів. Практичне значення отриманих результатів. Матеріали даної статті можливо використовувати у викладанні дисциплін «Міжнародна економіка», «Міжнародні економічні відносини» та «Міжнародні ринки інтернаціональний бізнес».

Ключові слова: паливно-енергетичний комплекс; енергетична безпека країни; структури енергопостачання; ринок природного газу; ефективність систем енергопостачання.

УДК 656.01; JEL Classification: R40

КаЛИНИченко Л.Л. БаГМУТ Л.С. МЕСТО УКРАИНСКОГО БИЗНЕСА В ЕВРОПЕЙСКОМ ЭНЕРГЕТИЧЕКОМ ПРОСТРАНСТВЕ

Цель исследования заключается в выявлении тенденций и закономерностей функционирования структур топливно-энергетического комплекса Украины и стран Европы. Методика исследования. Для достижения поставленной цели в научной работе были использованы методы 
анализа и синтеза, обобщения и абстрагирования - для систематизации тенденций развития главных отраслей топливно-энергетического комплекса. Метод комплексного подхода к анализу явлений помог осуществить структуризацию проблемных вопросов. Результаты исследования. При подготовке данной статьи рассмотрено значительное количество научных трудов и статей на тему энергетики и энергоснабжения в рамках европейского региона. Выявлено, что относительно главного вопроса энергетической безопасности у авторов нет расхождений. Системный анализ статистического материала позволил оформить важнейшие тенденции развития энергетики Евросоюза и Украины. Для стран Европы главным сдвигом в отраслях ТЭК является снижение доли ненадежных поставщиков энергоресурсов и чрезвычайно капиталоемкая политика замещения угольной генерации на ветряную и солнечную. Выявлены проблемы, существенно мешающие достижению самоокупаемости нашей страны: проблемы инвестиционного климата, проблемы неэффективного энергопотребления, низкий уровень экологической осведомленности населения. Проблема в государственной политике в области экологии и энергетики. В энергетическом пространстве Евросоюза можно отметить, что страны ЕС продолжают строить терминалы для приема сжиженного газа, что увеличивает их независимость; альтернативные источники энергии в Европе продолжают поддерживаться из бюджета. Научная новизна. Заключается в подчеркивании чрезвычайных мер стран Европейского союза по созданию разветвленной системы из многих поставщиков энергоресурсов. Практическое значение полученных peзультатов. Материалы данной статьи возможно использовать в преподавании дисциплин «Международная экономика», «Международные экономические отношения» и «Международные рынки международный бизнес».

Ключевые слова: топливно-энергетический комплекс; энергетическая безопасность страны; структуры энергоснабжения; рынок природного газа; эффективность систем энергоснабжения.

\section{UDC 656.01; JEL Classification: R40}

\section{Kalinichenko L. L., Bagmut L.S. PLACE OF UKRAINIAN BUSINESS IN THE EUROPEAN ENERGY SPACE}

Purpose of the study is to identify trends and patterns of functioning of the structures of the fuel and energy complex of Ukraine and European countries. Research methodology. To achieve this goal in scientific work, the methods of analysis and synthesis, generalization and abstraction were used to systematize the development trends of the main branches of the fuel and energy complex. The method of an integrated approach to the analysis of phenomena helped to structure the problematic issues. Methodology of research. In the preparation of this article, a significant number of scientific works and articles on the topic of energy and energy supply within the European region have been closely considered. It was revealed that the authors have no differences on the main issues of energy security. Findings. A 
systematic analysis of statistical material made it possible to formulate the most important trends in the development of the energy sector of the European Union and Ukraine. For European countries, the main shift in the fuel and energy sector is a decrease in the share of unreliable energy suppliers and an extremely capitalintensive policy of replacing coal generation with wind and solar. Problems that significantly hinder the achievement of self-sufficiency of our country have been identified: problems of the investment climate, problems of inefficient energy consumption, low level of environmental awareness of the population. The problem is the state policy in the field of ecology and energy. In the energy space of the European Union, it can be noted that the EU countries continue to build terminals for the reception of liquefied gas, which increases their independence; alternative energy sources in Europe continue to be supported from the budget. Originality. It is to emphasize the extraordinary measures of the European Union countries to create an extensive system of many energy suppliers. Practical value. The materials of this article can be used in teaching the disciplines «International Economics», «International Economic Relations» and «International Markets and International Business».

Key words: fuel and energy complex; energy security of the country; energy supply structures; natural gas market; efficiency of energy supply systems.

\section{Відомості про авторів / Сведения об авторах / About the Authors}

Калініченко Людмила Леонідівна - доктор економічних наук, професор, Харківський національний університет будівництва та архітектури, завідувач кафедри економіки; м. Харків, Україна; e-mail dkl11905@gmail.com ORCID: 0000-0001-9847-8448; т. 0506320580.

Калиниченко Людмила Леонидовна - доктор экономических наук, профессор, Харьковский национальный университет строительства и архитектуры, заведующая кафедрой экономики; г.Харьков, Украина;

Kalinichenko Liudmyla Leonidovna - Doctor of Economics, Professor, Kharkiv National University of Civil Engineering and Architecture, Head of the Department of Economics; Kharkiv, Ukraine.

Багмут Леонід Станіславович - кандидат економічних наук, доцент, Харківський національний університет будівництва та архітектури, доцент кафедри економіки та бізнесу, м. Харків, Україна; е-mail: leonid1956000@ gmail.com; ORCID:0000 - 0002 -1259- 5684; т. 705-28-98.

Багмут Леонид Станиславович - кандидат экономических наук, доцент, Харьковский национальный університет строительства и архитектуры, доцент кафедры экономики и бизнеса, г. Харьков, Украина.

Bagmut Leonid Stanislavovich - Candidate of Economic Sciences, Associate

Professor, Kharkiv National University of Civil Engineering and Architecture,, Associate Professor of the Department of Economics and Business, Kharkov, Ukraine. 